\title{
MODEL FUNGSI TRANSFER MULTI INPUT UNTUK PERAMALAN CURAH HUJAN DI KOTA SURABAYA
}

\section{(Multi Input Transfer Function Model For Forecasting Rainfall In The City Of Surabaya)}

\author{
Yonlib W. A. Nanlohy ${ }^{1^{*}}$, Brodjol Sutijo S. U. ${ }^{2}$, Santi Wulan $\mathbf{P}^{3}$ \\ ${ }^{1}$ Program Studi Statistika Fakultas Matematika dan Ilmu Pengetahuan Alam, Universitas Pattimura \\ Jl. Ir. M. Putuhena, Ambon, 97233, Maluku, Indonesia \\ ${ }^{2}$ Departemen Statistika, Fakultas Matematika, Komputasi, dan Sains Data, Institut Teknologi Sepuluh \\ Nopember \\ Jl. Arief Rahman Hakim, Surabaya, 60111, Jawa Timur, Indonesia
}

e-mail: ywa.nanlohy@gmail.com ${ }^{I^{*}}$,brodjol_su@statistika.its.ac.id ${ }^{2}$, santiwulan08@gmail.com ${ }^{3}$

\begin{abstract}
Abstrak: Surabaya merupakan kota terbesar yang berada di provinsi Jawa Timur dan sekaligus menjadi menjadi pusat pemerintahan provinsi. Untuk karakteristik iklim di Surabaya umumnya suhu terendah pada bulan Februari sekitar $25,5^{\circ} \mathrm{C}$ dan suhu tertinggi sekitar $33,0^{\circ} \mathrm{C}$ pada bulan Oktober. Di Kota Surabaya musim kemarau pada umumnya berada pada bulan Mei sampai Oktober dan musim hujan dari bulan November hingga April. Hujan lebat biasanya terjadi antara bulan Desember dan Januari. Salah satu dampak negatif yang ditimbulkan akibat intensitas curah hujan berlebih di Kota Surabaya adalah banjir. Metode yang sering kali digunakan untuk meramalkan curah hujan di Kota Surabaya yaitu Autoregressive Integrated Moving Average (ARIMA). Model ARIMA merupakan model peramalan analisis data deret waktu tunggal atau model univariat. Terdapat beberapa unsur cuaca (suhu, kelembaban udara, dan kecepatan angin) yang mempengaruhi curah hujan sehingga perlu dilakukan peramalan dengan menggunakan model multivariat. Model fungsi transfer multi input merupakan model peramalan analisis deret waktu berganda (multiple) untuk model multivariat. Pada model fungsi transfer multi input terdapat deret output $\left(y_{t}\right)$ yang diperkirakan akan dipengaruhi oleh deret input $\left(x_{t}\right)$ dan input-input lain yang digabungkan dalam satu kelompok yang disebut deret noise $\left(n_{t}\right)$. Tujuan dari penelitian ini yaitu untuk meramalkan curah hujan harian di Kota Surabaya dengan model fungsi transfer multi input.
\end{abstract}

Kata Kunci: ARIMA, curah hujan, fungsi transfer multi input.

\begin{abstract}
Surabaya is the largest city in the province of East Java and is also the center of the provincial government. In October, the temperature was around $33.5^{\circ} \mathrm{C}$ and the highest temperature was $33.0^{\circ} \mathrm{C}$ in October. In the city of Surabaya the dry season is from May to October and the rainy season is from November to April. Heavy rain usually occurs between December and January. One of the negative impacts caused by excessive rainfall in the city of Surabaya is flooding. The method is often used to predict rainfall in the city of Surabaya, it is Autoregressive Integrated Moving Average (ARIMA). ARIMA models is forecasting model analysis data of single time series or univariate models. There are several elements of weather (temperature, humidity and wind speed) that influenced a rainfall, so that needs to be done forecasting by using a multivariat model. In the multi input transfer function model there is an output series $\left(y_{t}\right)$ that expected to be influenced by the input series $\left(x_{t}\right)$ and the other inputs are combined into one group is called noise series $\left(n_{t}\right)$. The purpose of this study is to forecast the daily rainfall in the city of Surabaya with a multi-input transfer function model.
\end{abstract}

Keywords: ARIMA, Curah Hujan, Fungsi Transfer Multi Input. 
Volume 1 Nomor 2 | Desember 2019

\section{PENDAHULUAN}

Peramalan data deret waktu pada dasarnya adalah analisis univariat, sedangkan dalam kenyataan, sebagian besar pengamatan merupakan data multivariat. Peranan peramalan telah menjelajah ke berbagai bidang diantaranya bidang meteorologi yang menyangkut peramalan cuaca dan curah hujan.

Surabaya merupakan kota terbesar yang berada di provinsi Jawa Timur dan sekaligus menjadi menjadi pusat pemerintahan provinsi. Secara geografis Surabaya memiliki luas wilayah $326,81 \mathrm{~km}^{2}$ dan rata-rata curah hujan berkisar 1,321 mm per tahun. Untuk karakteristik iklim di Surabaya umumnya suhu terendah pada bulan Februari sekitar 25,5 celcius dan suhu tertinggi sekitar 33,0 celcius pada bulan Oktober. Di Kota Surabaya musim kemarau pada umumnya berada pada bulan Mei sampai Oktober dan musim hujan dari bulan November hingga April. Hujan lebat biasanya terjadi antara bulan Desember dan Januari [1]. Salah satu dampak negatif yang ditimbulkan akibat intensitas curah hujan berlebih di Kota Surabaya adalah banjir. Hujan bukanlah faktor utama yang menyebabkan meluapnya air sungai, tetapi lebih disebabkan kondisi lingkungan yang kurang baik, banyaknya sampah yang menyumbat aliran air sehingga aliran air hujan tidak bisa mengalir dengan lancar, dan juga disebabkan sistem drainase yang kurang baik. Namun jika hujan dapat diprediksi hal ini akan dapat membantu pihak pemerintah dan masyarakat untuk mempersiapkan diri sebagai langkah mengantisipasi bila hujan dengan intensitas tinggi tiba di Kota Surabaya.

Metode yang sering kali digunakan untuk meramalkan curah hujan yaitu Autoregressive Integrated Moving Average (ARIMA). Model ARIMA merupakan model peramalan analisis data deret waktu tunggal atau model univariat. Penelitian yang pernah dilakukan untuk meramalkan curah hujan dengan menggunakan ARIMA di Kota Surabaya antara lain oleh [2] tentang pemodelan ARIMA dengan deteksi outlier terhadap data curah hujan dan [3] tentang peramalan data curah hujan dengan Seasonal Autoregregressive Integrated Moving Average (SARIMA). Model ARIMA pada penelitian sebelumnya di Kota Surabaya hanya melihat ketergantungan curah hujan pada data masa lalu tanpa melibatkan ketergantungan curah hujan dengan variabel lain. Menurut [4] pada kasus curah hujan terdapat hubungan dari unsur-unsur cuaca lain seperti suhu, kelembaban udara, dan kecepatan angin. Karena terdapat beberapa unsur cuaca (suhu, kelembaban udara, dan kecepatan angin) yang mempengaruhi curah hujan sehingga perlu dilakukan peramalan dengan menggunakan model multivariat. Model multivariat yang dapat digunakan untuk meramalkan curah hujan dengan memperhatikan faktor-faktor yang mempengaruhinya yaitu model fungsi transfer.

Model fungsi transfer merupakan model peramalan analisis deret waktu berganda (multiple) untuk model multivariat. Pada model fungsi transfer terdapat deret output $\left(y_{t}\right)$ yang diperkirakan akan dipengaruhi oleh deret input $\left(x_{t}\right)$ dan input-input lain yang digabungkan dalam satu kelompok yang disebut deret noise $\left(n_{t}\right)$ [5]. Beberapa penelitian yang pernah dilakukan dengan menggunakan fungsi transfer ini antara lain oleh [6] melakukan evaluasi proses pembuatan bir dengan fungsi transfer dan logika fuzzy, dan [7] melakukan kajian model intervensi dan model fungsi transfer mengenai peluang bisnis pada jasa kereta api Indonesia dalam menyikapi krisis ekonomi. Tujuan dari penelitian ini untuk mendapatkan model peramalan curah hujan terbaik dan input atau faktor-faktor yang mempengaruhi curah hujan di Kota Surabaya menggunakan model fungsi transfer multi input.

\subsection{Autoregressive Integrated Moving Avarage (ARIMA)}

Model ARIMA merupakan model kombinasi dari autoregressive (AR) berordo $p$ dan proses moving average (MA) berordo $q$. Pembeda berordo $d$ dilakukan jika data deret waktu tidak stasioner dalam ratarata. Pemeriksaan kestasioneran data dapat dilihat dari Time Series Plot, Autocorrelation Function (ACF) Plot dan Partial Autocorrelation Function (PACF) Plot. Model ARIMA $(p, d, q)$ dapat ditulis sebagai berikut [8]:

$$
\phi_{p}(B)(1-B)^{d} Y_{t}=\theta_{q}(B) a_{t}
$$


Model ARIMA yang mengakomodasi efek musiman dalam pengamatan waktu ke- $t$ dinotasikan dengan $\operatorname{ARIMA}(P, D, Q)^{S}$. Secara umum, model ARIMA musiman dapat ditulis dalam bentuk:

$$
\Phi_{P}\left(B^{S}\right)\left(1-B^{S}\right)^{D} Y_{t}=\Theta_{Q}\left(B^{S}\right) a_{t}
$$

Jika terdapat efek non-musiman dan efek musiman, maka model yang terbentuk adalah model multiplikatif yaitu ARIMA $(p, d, q)(P, D, Q)^{S}$. Bentuk umum model ARIMA $(p, d, q)(P, D, Q)^{S}$ dapat ditulis sebagai berikut:

$$
\phi_{p}(B) \Phi_{P}\left(B^{s}\right)(1-B)^{d}\left(1-B^{s}\right)^{D} Y_{t}=\theta_{q}(B) \Theta_{Q}\left(B^{s}\right) a_{t}
$$

\subsection{Fungsi Transfer}

Pembentukan model fungsi transfer didasarkan pada autocorrelation function (ACF) dan cross correlation function (CCF). Bentuk umum model fungsi transfer untuk input tunggal, $x_{t}$, dan output tunggal, $y_{t}$, adalah:

$$
\begin{gathered}
y_{t}=v_{0} x_{t}+v_{1} x_{t-1}+v_{2} x_{t-2}+\cdots+n_{t} \\
y_{t}=v(B) x_{t}+n_{t} \\
y_{t}=\frac{\omega_{s}(B) B^{b}}{\delta_{r}(B)} x_{t}+\frac{\theta(B)}{\phi(B)} a_{t}
\end{gathered}
$$

\subsection{Fungsi Transfer Multi Input}

Secara umum, deret output mungkin dipengaruhi oleh beberapa deret input, sehingga model kausal untuk fungsi transfer multi input adalah:

$$
y_{t}=v_{1}(B) x_{1 t}+\cdots+v_{m}(B) x_{m t}+n_{t}
$$

atau

$$
y_{t}=\sum_{j=1}^{m} v_{j}(B) x_{j t}+n_{t}
$$

atau

$$
y_{t}=\sum_{j=1}^{m} \frac{\omega_{j}(B)}{\delta_{j}(B)} B^{b j} x_{j t}+\frac{\theta(B)}{\phi(B)} a_{t}
$$

\section{METODOLOGI}

\subsection{Sumber Data}

Data yang digunakan adalah data curah hujan harian di Kota Surabaya. Data yang digunakan adalah data dari Januari tahun 2008 sampai dengan Desember 2015. Data dibagi menjadi data in-sample sebagai data training dan data out-sample sebagai data testing. Data in-sample digunakan data dari Januari 2008 sampai November 2015 dan data out-sample yang digunakan data Desember tahun 2015.

\subsection{Variabel Penelitian}

Berdasar pada latar belakang dan tujuan penelitian, terdapat satu deret input dan tiga deret output yang digunakan sebagai berikut:

Deret Output $Y$ : Curah Hujan Harian di Kota Surabaya

Deret Input $X_{I}$ : Suhu Udara

$$
X_{2} \text { : Kelembaban Udara }
$$




$$
X_{3} \text { : Kecepatan Angin }
$$

\subsection{Tahapan Penelitian}

Penelitian ini menggunakan software SAS dan Minitab. Tahapan peramalan dengan metode fungsi transfer multi input sebagai berikut:

1. Mengidentifikasi bentuk model fungsi transfer melalui tahapan sebagai berikut:

a. Pre-whitening deret input: membentuk model ARIMA untuk masing-masing deret input melalui tahap identifikasi model, estimasi parameter model dan pengujian model sehingga mendapatkan nilai pre-whitening deret input.

b. Pre-whitening deret output.

c. Perhitungan cross correlation setiap deret input dan deret output yang telah melalui proses prewhitening.

d. Penetapan $(b, r, s)$ model fungsi transfer untuk setiap deret input.

e. Estimasi parameter model fungsi transfer.

f. penghitungan deret noise $\left(n_{t}\right)$ dari fungsi transfer multi input.

g. Penetapan $\left(p_{n}, q_{n}\right)$ untuk model ARIMA $\left(p_{n}, 0, q_{n}\right)$ dari deret noise $\left(n_{t}\right)$.

2. Uji diagnosis model fungsi transfer multi input.

3. Melakukan peramalan data curah hujan harian dengan menggunakan model fungsi transfer multi input.

4. Menghitung nilai Root Mean Square Error (RMSE).

\section{HASIL DAN PEMBAHASAN}

\subsection{Identifikasi Model Fungsi Transfer Multi Input}

Data dibagi menjadi data in-sample dan out-sample. Data in-sample yang digunakan untuk pemodelan adalah data dari bulan Januari 2008 sampai November 2015. Sedangkan data out-sample adalah data bulan Desember 2015. Data akan dimodelkan ARIMA yang sesuai kemudian dimodelkan dengan model fungsi transfer. Berikut Time Series Plot deret input dan deret output.

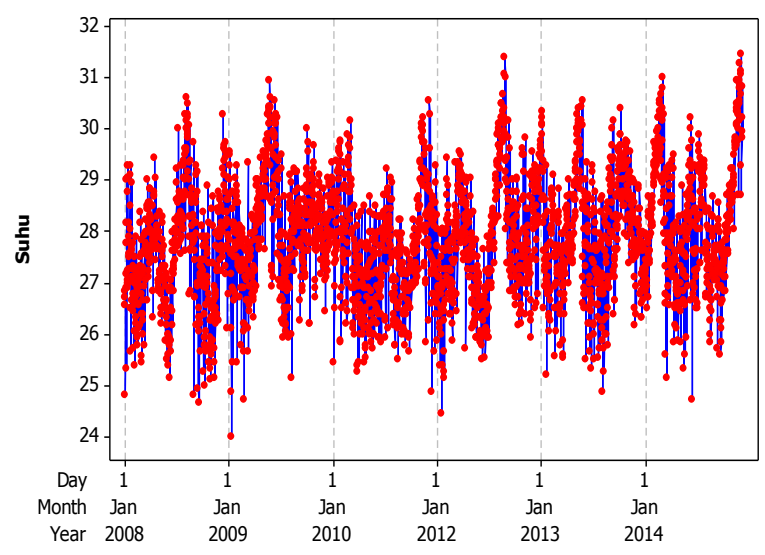

(a)

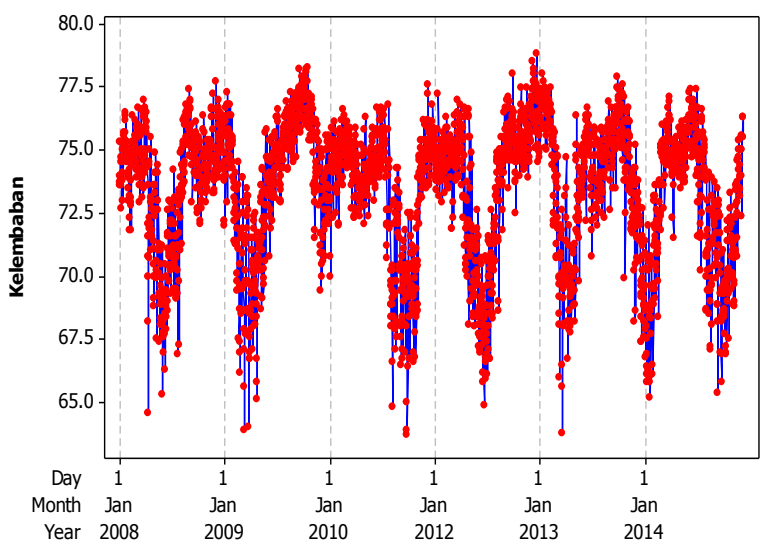

(b) 


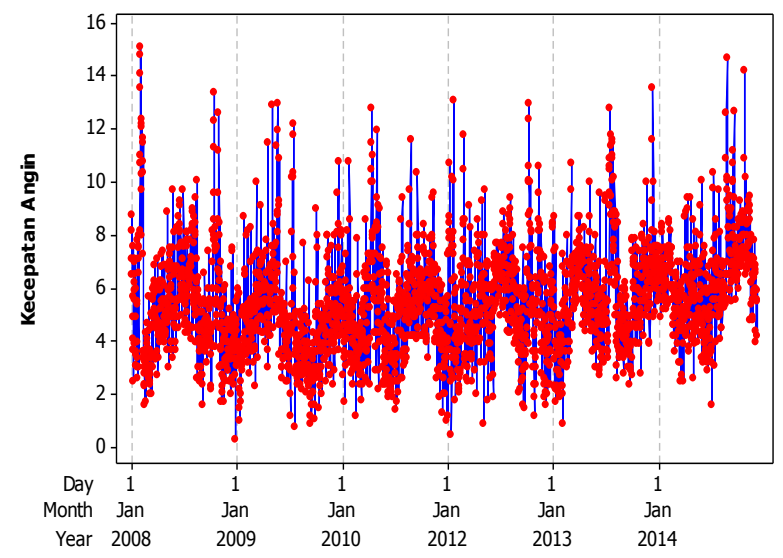

(c)

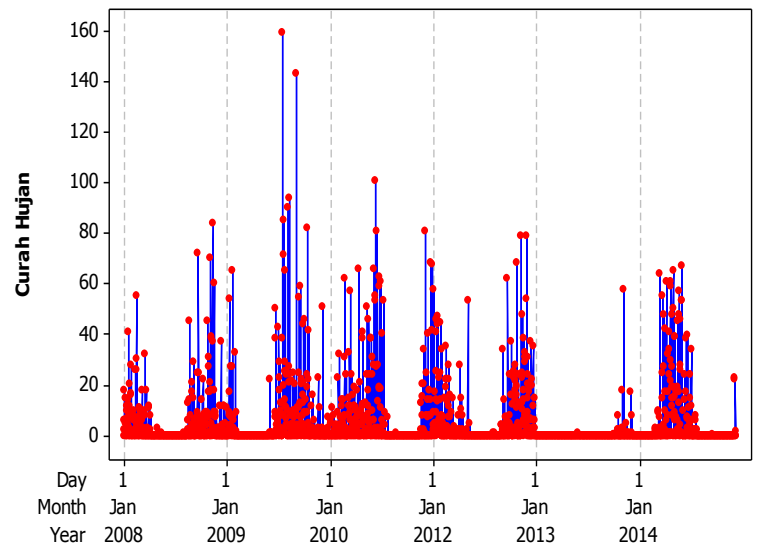

(d)

Gambar 1. Time Series Plot Suhu (a), Kelembaban (b), Kecepatan Angin (c) dan Curah Hujan (d) Harian di Kota Surabaya

Berdasarkan Gambar 1(a) dan 1(b), suhu harian dan kecepatan angin harian di Kota Surabaya cenderung stasioner sedangkan pada Gambar 1(c), kelembaban harian di Kota Surabaya tidak stasioner dan cenderung membentuk pola musiman. sedangkan Gambar 1(d), curah hujan harian di Kota Surabaya cenderung tidak stasioner dan banyak outlier.

Asumsi dasar yang harus dipenuhi dalam analisis time series dan pembentukan model fungsi transfer adalah stasioneritas data baik dalam varians maupun dalam rata-rata. Pemeriksaan stasioneritas data dalam varians dapat dilakukan dengan menggunakan Box-Cox plot. Jika data belum stasioner dalam varians maka perlu dilakukan transformasi pada data. Gambar 2 berikut menampilkan Box-Cox plot dari data suhu, kelembaban, dan kecepatan angin harian di Kota Surabaya yang telah stasioner dalam varians.

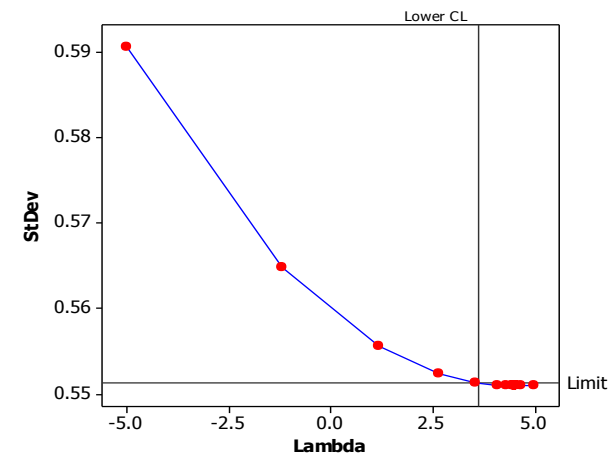

(a)
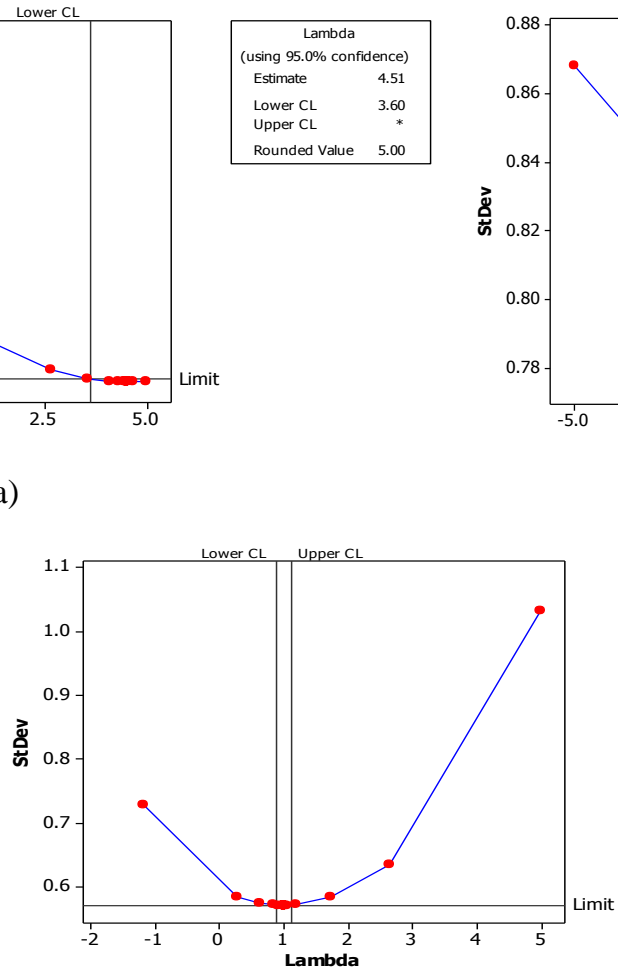

(c)

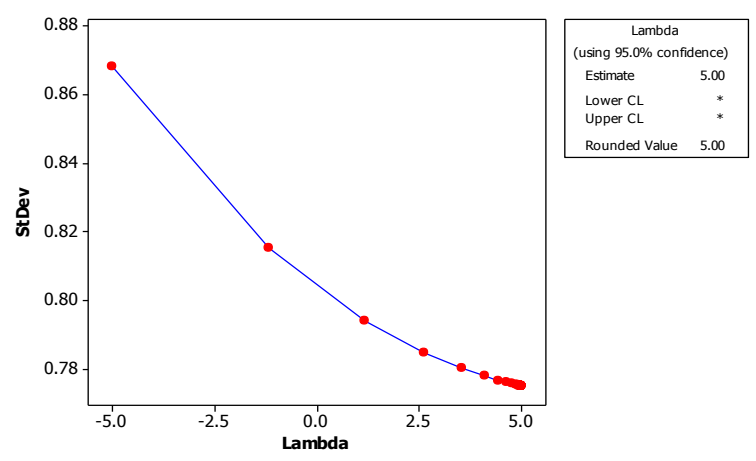

(b)

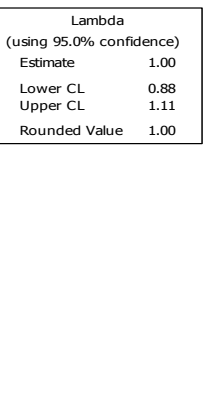

(b), Kecepatan Angin (c) Harian di Kota Surabaya 
Gambar 2(a) dan 2(b) menunjukan nilai $\lambda>1$ dan Gambar 2(c) menunjukan nilai $\lambda=1$ maka diasumsikan data stasioner dalam varians. Selanjutnya dilakukan pemeriksaan kestasioneran data dalam rata-rata. Pemeriksaan kestasioneran data dalam rata-rata dapat dilakukan dengan menggunakan plot ACF dan PACF.
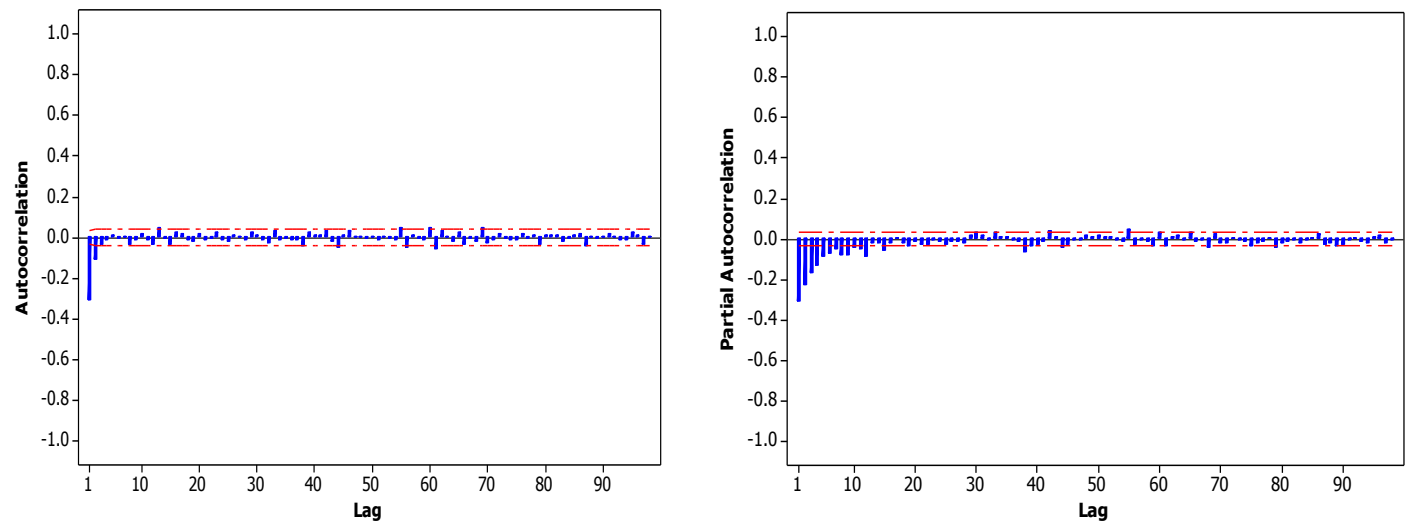

Gambar 3. ACF dan PACF Plot Suhu Harian di Kota Surabaya setelah differencing pada lag-1
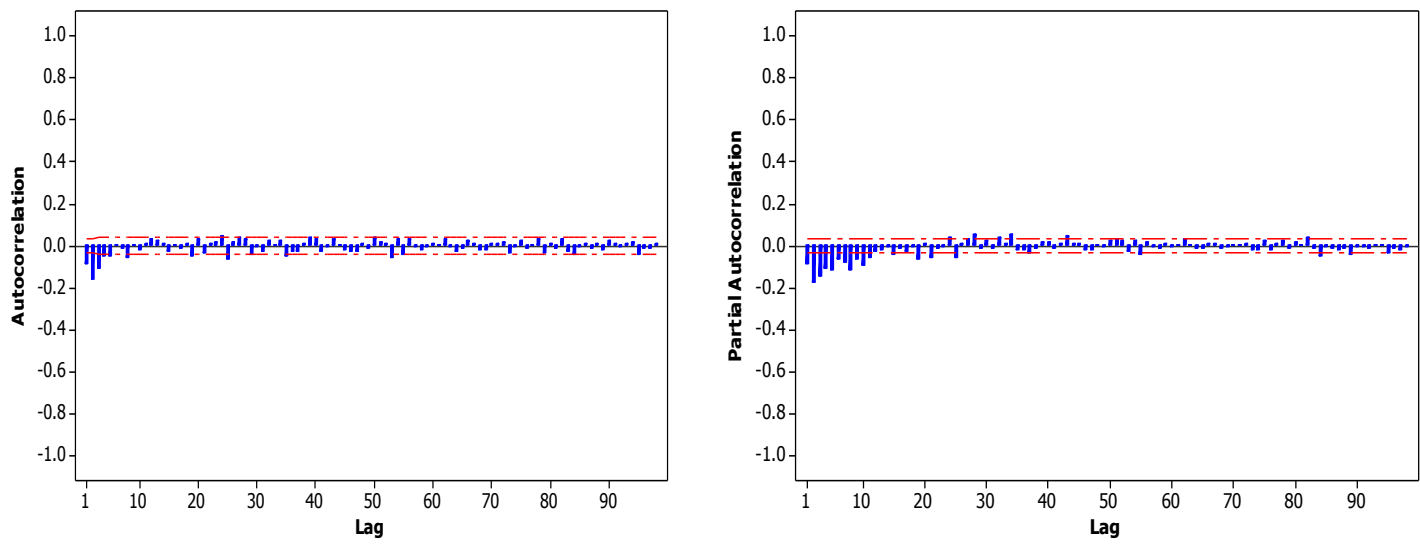

Gambar 4. ACF dan PACF Plot Kelembaban Harian di Kota Surabaya setelah differencing pada lag-1
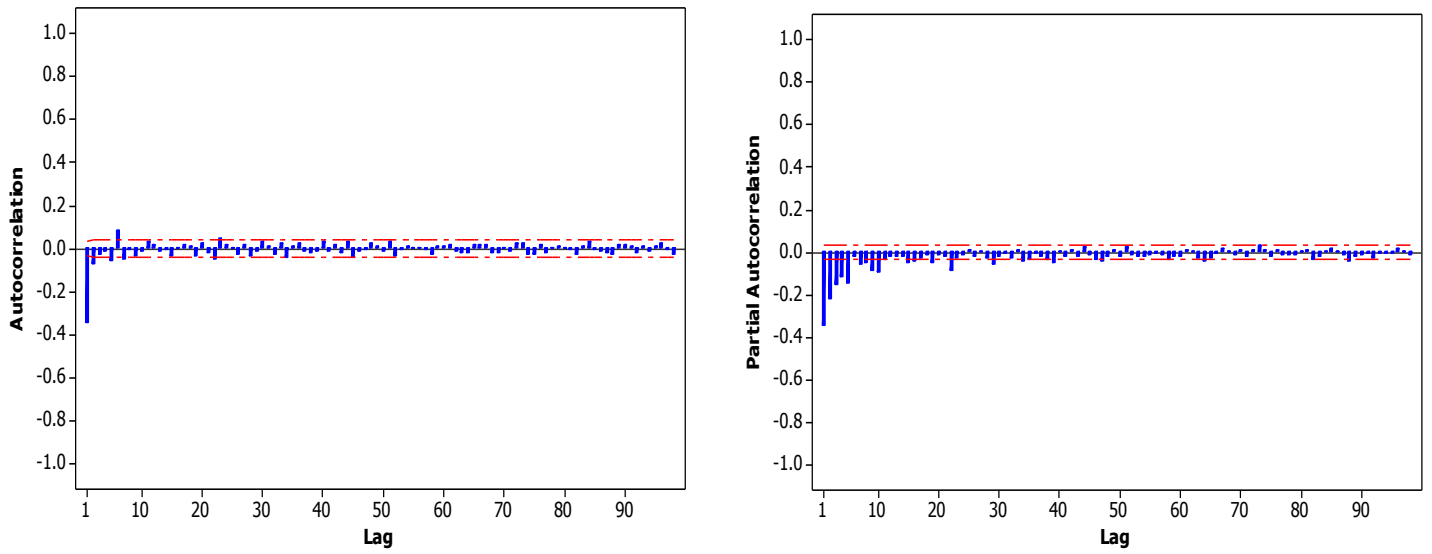

Gambar 5. ACF dan PACF Plot Kecepatan Angin Harian di Kota Surabaya setelah differencing pada lag-1

Berdasarkan plot ACF dan PACF masing-masing deret input yang telah stasioner dalam rata-rata selanjutnya dibentuk model ARIMA sesuai lag-lag yang signifikan pada plot ACF dan PACF. Hasil identifikasi dari lag yang signifikan pada plot ACF dan PACF, diperoleh model ARIMA untuk suhu yaitu 
Nanlohy, dkk | Model Fungsi Transfer Multi Input ...

ARIMA([1,8],1,[1,33]), kelembaban yaitu ARIMA ([2,8,19],1,[1,2,3,20,24,25]) dan kecepatan angin yaitu ARIMA $([1,5,7], 1,[1,2,5,6])$.

\subsection{Pre-whitening Deret Input dan Output}

Model yang terbentuk untuk suhu harian di Kota Surabaya adalah:

$$
\begin{gathered}
X_{1 t}=1,36673 X_{1 t-1}-0,36673 X_{1 t-2}-0,05154 X_{1 t-8}+0,05154 X_{1 t-9}+a_{t}-0,84504 a_{t-1} \\
-0,02894 a_{t-33}
\end{gathered}
$$

Sehingga deret input suhu harian di Kota Surabaya yang telah melalui proses pre-whitening adalah:

$$
\begin{gathered}
\alpha_{1 t}=X_{1 t}-1,36673 X_{1 t-1}+0,36673 X_{1 t-2}+0,05154 X_{1 t-8}-0,05154 X_{1 t-9}+0,84504 \alpha_{1 t-1} \\
+0,02894 \alpha_{1 t-33}
\end{gathered}
$$

Pre-whitening deret output (curah hujan harian di Kota Surabaya) mengikuti pre-whitening deret input. Sehingga deret output curah hujan harian di Kota Surabaya yang telah melalui proses pre-whitening adalah:

$$
\begin{gathered}
\beta_{1 t}=Y_{1 t}-1,36673 Y_{1 t-1}+0,36673 Y_{1 t-2}+0,05154 Y_{1 t-8}-0,05154 Y_{1 t-9}+0,84504 \beta_{1 t-1} \\
+0,02894 \beta_{1 t-33}
\end{gathered}
$$

Model yang terbentuk untuk kelembaban harian di Kota Surabaya adalah:

$X_{2 t}=X_{2 t-1}+0,23148 X_{2 t-2}-0,23148 X_{2 t-3}-0,05979 X_{2 t-8}+0,05979 X_{2 t-9}+$

$0,05011 X_{2 t-19}-0,05011 X_{2 t-20}+a_{2 t}-0,18905 a_{2 t-1}-0,48247 a_{2 t-2}-0,10826 a_{2 t-3}+$

$0,04514 a_{2 t-20}+0,05447 a_{2 t-24}-0,04367 a_{2 t-25}$

Sehingga deret input kelembaban harian di Kota Surabaya yang telah melalui proses pre-whitening adalah:

$\alpha_{2 t}=X_{2 t}-X_{2 t-1}-0,23148 X_{2 t-2}+0,23148 X_{2 t-3}+0,05979 X_{2 t-8}-0,05979 X_{2 t-9}-$

$0,05011 X_{2 t-19}+0,05011 X_{2 t-20}+0,18905 a_{2 t-1}+0,48247 a_{2 t-2}+0,10826 a_{2 t-3}-$

$0,04514 a_{2 t-20}-0,05447 a_{2 t-24}+0,04367 a_{2 t-25}$

Pre-whitening deret output (curah hujan harian di Kota Surabaya) mengikuti pre-whitening deret input. Sehingga deret output curah hujan harian di Kota Surabaya yang telah melalui proses pre-whitening adalah:

$\beta_{2 t}=Y_{2 t}-Y_{2 t-1}-0,23148 Y_{2 t-2}+0,23148 Y_{2 t-3}+0,05979 Y_{2 t-8}-0,05979 Y_{2 t-9}-$

$0,05011 Y_{2 t-19}+0,05011 Y_{2 t-20}+0,18905 \beta_{2 t-1}+0,48247 \beta_{2 t-2}+0,10826 \beta_{2 t-3}-$

$0,04514 \beta_{2 t-20}-0,05447 \beta_{2 t-24}+0,04367 \beta_{2 t-25}$

Model yang terbentuk untuk kecepatan harian di Kota Surabaya adalah:

$X_{3 t}=1,58790 X_{3 t-1}-0,58790 X_{3 t-2}+0,33046 X_{3 t-5}-0,33046 X_{3 t-6}-0,08355 X_{3 t-7}+$

$0,08355 X_{3 t-8}+a_{3 t}-1,12817 a_{3 t-1}+0,19869 a_{3 t-2}-0,35003 a_{3 t-5}+0,28300 a_{3 t-6}$

Sehingga deret input kecepatan angin harian di Kota Surabaya yang telah melalui proses pre-whitening adalah:

$\alpha_{3 t}=$

$X_{3 t}-1,58790 X_{3 t-1}+0,58790 X_{3 t-2}-0,33046 X_{3 t-5}+0,33046 X_{3 t-6}+0,08355 X_{3 t-7}-$

$0,08355 X_{3 t-8}+1,12817 a_{3 t-1}-0,19869 a_{3 t-2}+0,35003 a_{3 t-5}-0,28300 a_{3 t-6}$

Pre-whitening deret output (curah hujan harian di Kota Surabaya) mengikuti pre-whitening deret input. Sehingga deret output curah hujan harian di Kota Surabaya yang telah melalui proses pre-whitening adalah:

$\beta_{3 t}=Y_{3 t}-1,58790 Y_{3 t-1}+0,58790 X_{3 t-2}-0,33046 Y_{3 t-5}+0,33046 Y_{3 t-6}+0,08355 Y_{3 t-7}-$

$0,08355 Y_{3 t-8}+1,12817 \beta_{3 t-1}-0,19869 \beta_{3 t-2}+0,35003 \beta_{3 t-5} 0,28300 \beta_{3 t-6}$ 


\subsection{Identifikasi Deret Noise dan Uji Diagnosis}

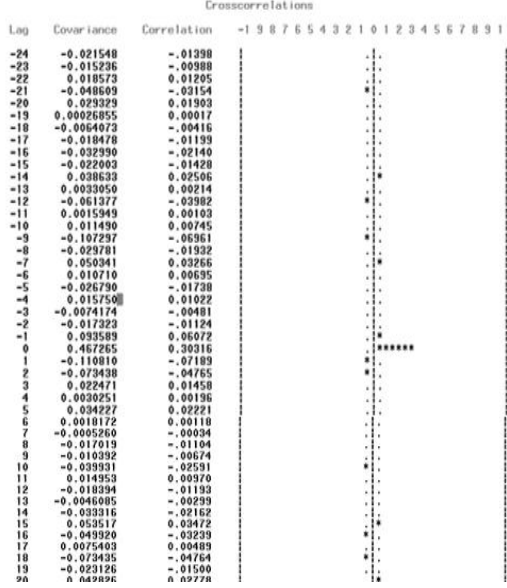

(a)
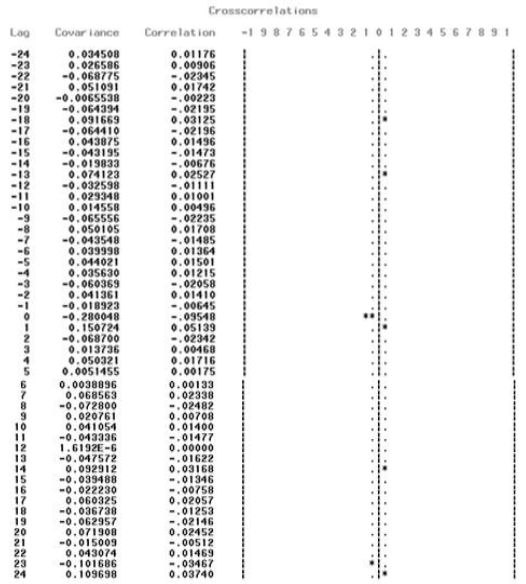

(b)
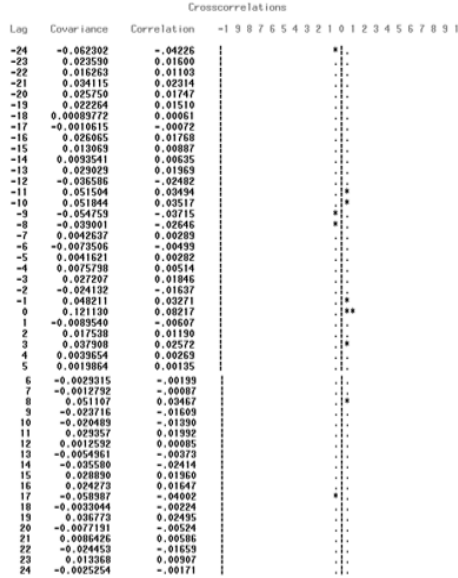

(c)

Gambar 6. Plot CCF Suhu (a), Kelembaban (b) dan Kecepatan Angin (c) dengan Curah Hujan

Berdasarkan Gambar 6 didapatkan orde $(b, r, s)$ untuk input suhu orde $(b=0, r=0, s=[1,2])$, kelembaban orde $(b=0, r=0, s=0)$, dan kecepatan angin orde $(b=0, r=0, s=0)$. Sehingga dapat dibentuk model awal fungsi transfer multi input sebagai berikut:

$$
Y_{t}=\left(\omega_{01}-\omega_{11} B-\omega_{21} B^{2}\right) X_{1 t}+\omega_{02} X_{2 t}+\omega_{03} X_{3 t}+n_{t}
$$

Tabel 1. Uji Signifikansi Parameter Model Awal Fungsi Transfer Multi Input Terhadap Curah Hujan Harian di Kota Surabaya

\begin{tabular}{|l|l|l|l|l|l|}
\hline Input & Orde $(b, r, s)$ & Parameter & Estimasi & P-value & Keputusan \\
\hline \multirow{3}{*}{ Suhu } & \multirow{2}{*}{$(b=0, r=0, s=2)$} & $\omega_{01}$ & 0,85855 & $<0,0001$ & Signifikan \\
\cline { 3 - 6 } & & $\omega_{11}$ & 0,19066 & 0,0013 & Signifikan \\
\cline { 3 - 6 } & $\omega_{21}$ & 0,16067 & 0,0043 & Signifikan \\
\hline Kelembaban & $(b=0, r=0, s=0)$ & $\omega_{02}$ & $-0,27581$ & $<0,0001$ & Signifikan \\
\hline Kecepatan Angin & $(b=0, r=0, s=0)$ & $\omega_{03}$ & $-0,07032$ & 0,2036 & Tidak Signifikan \\
\hline
\end{tabular}

Tabel 1 menunjukan bahwa input kecepatan angin tidak signifikan karena nilai p-value $>0,05$, sedangkan input suhu dan kelembaban sudah signifikan dengan nilai p-value $<0,05$.

$$
Y_{t}=\left(\omega_{01}-\omega_{11} B-\omega_{21} B^{2}\right) X_{1 t}+\omega_{02} X_{2 t}+n_{t}
$$

Selanjutnya akan dilakukan pemodelan ARIMA terhadap deret noise $\left(n_{t}\right)$ sehingga mendapatkan residual yang white noise.
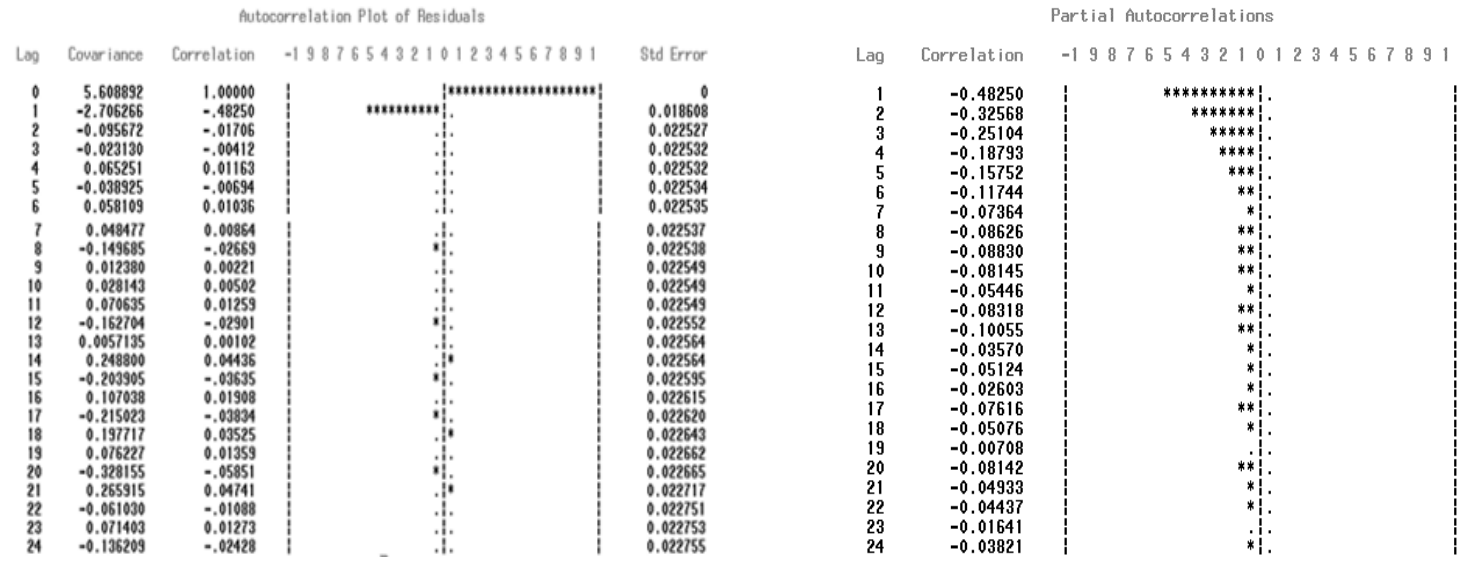

Gambar 7. Plot ACF dan PACF Deret Noise $\left(n_{t}\right)$ 
Berdasarkan Gambar 7 maka model ARIMA untuk deret noise $\left(n_{t}\right)$ adalah ARIMA ([8],[1,21]). Hasil estimasi parameter model fungsi transfer multi input (FTMI) berdasarkan model ARIMA ([8],[1,21]) seperti ditunjukkan pada Tabel 2 berikut.

Tabel 2. Uji Signifikansi Parameter Model Akhir Fungsi Transfer Multi Input (FTMI)

\begin{tabular}{|c|c|c|c|l|}
\hline Model & Parameter & Estimasi & P-value & Keputusan \\
\hline \multirow{3}{*}{$\begin{array}{c}\text { FTMI } \\
(b=0, r=0, s \\
=2)\end{array}$} & $\phi_{8}$ & $-0,03833$ & 0,0458 & Signifikan \\
\cline { 2 - 5 }$(b=0, r=0, s$ & $\theta_{1}$ & 0,92177 & $<, 0001$ & Signifikan \\
\cline { 2 - 5 } $\begin{array}{c}\text { = }) \\
\text { ARIMA } \\
([8],[1,21]\end{array}$ & $\theta_{21}$ & $-0,01734$ & 0,0182 & Signifikan \\
\cline { 2 - 5 } & $\omega_{01}$ & 1,01041 & $<, 0001$ & Signifikan \\
\cline { 2 - 5 } & $\omega_{11}$ & 0,10714 & 0,0250 & Signifikan \\
\cline { 2 - 5 } & $\omega_{12}$ & 0,10268 & 0,0178 & Signifikan \\
\hline
\end{tabular}

Tabel 2 menunjukan bahwa semua parameter signifikan karena nilai p-value $>0,05$. Selanjutnya dilakukan pengecekan kelayakan model dengan menguji asumsi white noise dan normalitas dari residual model yang dihasilkan. Hasil uji asumsi seperti pada Tabel 3 di bawah ini.

Tabel 3. Uji White Noise Residual Model Fungsi Transfer Multi Input (FTMI) terhadap Curah Hujan Harian Kota Surabaya

\begin{tabular}{|c|c|c|c|c|}
\hline Model & Lag & Chi-Square & P-value & Keputusan \\
\hline \multirow{4}{*}{$\begin{array}{c}\text { FTMI-ARIMA } \\
([8],[1,21])\end{array}$} & 6 & 1,85 & 0,6038 & \\
\cline { 2 - 4 }$(b=0, r=0, s=$ & 12 & 5,23 & 0,8138 & \\
\cline { 2 - 4 } & 18 & 15,18 & 0,4382 & \multirow{3}{*}{ White } \\
\cline { 2 - 4 } 1,2$)$ & 24 & 21,67 & 0,4188 & noise \\
\cline { 2 - 4 } & 30 & 28,32 & 0,3947 & \\
\cline { 2 - 4 } & 36 & 38,49 & 0,2350 & \\
\cline { 2 - 4 } & 42 & 48,00 & 0,1529 & \\
\cline { 2 - 4 } & 48 & 55,53 & 0,1351 & \\
\hline
\end{tabular}

Berdasarkan Tabel 3, model fungsi transfer multi input sudah memenuhi asumsi white noise dengan nilai p-value $>0,05$ pada semua lag. Untuk uji normalitas residual dengan uji Kolmogorov-Smirnov diperoleh nilai $\mathrm{p}$-value $<0,05$ sehingga dapat disimpulkan bahwa residual model fungsi transfer multi input belum berdistribusi normal. Hal ini disebabkan karena adanya outlier sesuai Gambar 8.

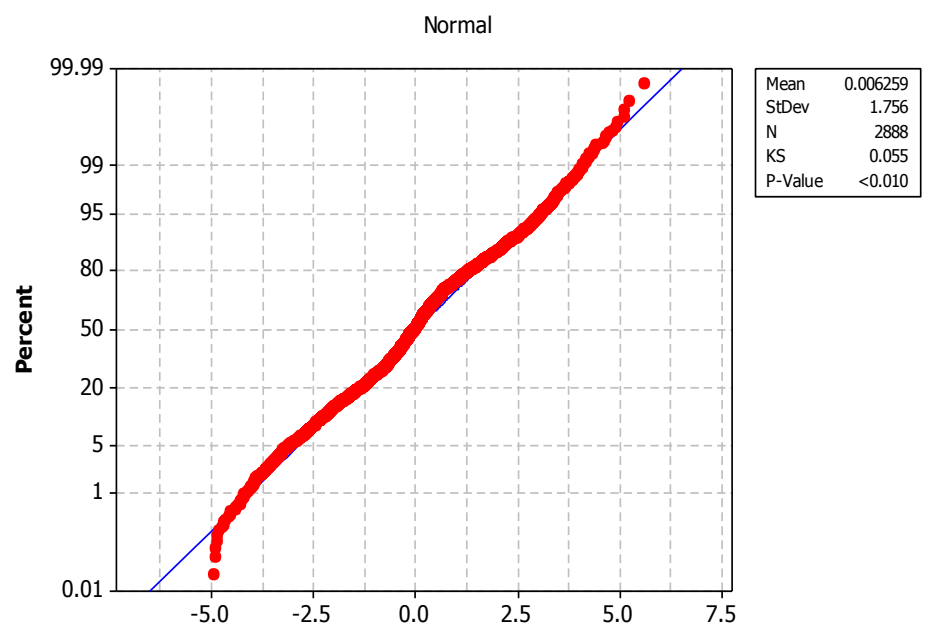

Gambar 8. Plot Kenormalan Residual Model Fungsi Transfer Multi Input

Gambar 8 menunjukan residual tidak berdistribusi normal karena adanya outlier, sehingga estimasi parameter model fungsi transfer multi input dilanjutkan dengan menambahkan deteksi outlier. Hasil estimasi parameter model dengan melibatkan deteksi outlier disajikan pada Tabel 4. 
Tabel 4. Uji Signifikansi Model Akhir Fungsi Transfer Multi Input (FTMI) dengan Deteksi Outlier

\begin{tabular}{|c|c|c|c|c|}
\hline Model & Parameter & Estimasi & P-value & Keputusan \\
\hline \multirow{11}{*}{ 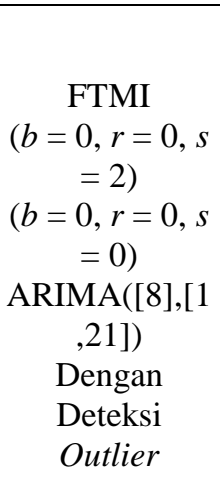 } & $\phi_{8}$ & -0.07062 & 0.0003 & Signifikan \\
\hline & $\theta_{1}$ & 0.97808 & $<0.0001$ & Signifikan \\
\hline & $\theta_{21}$ & -0.08653 & $<0.0001$ & Signifikan \\
\hline & $\omega_{01}$ & 1.08721 & $<0.0001$ & Signifikan \\
\hline & $\omega_{11}$ & 0.14210 & 0.0009 & Signifikan \\
\hline & $\omega_{12}$ & 0.10603 & 0.0045 & Signifikan \\
\hline & $\omega_{02}$ & -0.29477 & $<0.0001$ & Signifikan \\
\hline & $\omega_{L S 1914}$ & 2.58556 & $<0.0001$ & Signifikan \\
\hline & $\omega_{L S 1955}$ & 3.76015 & $<0.0001$ & Signifikan \\
\hline & $\omega_{L S 1500}$ & 2.36799 & $<0.0001$ & Signifikan \\
\hline & $\vdots$ & $\vdots$ & $\vdots$ & $\vdots$ \\
\hline & $\omega_{A O 411}$ & -3.40290 & 0.0249 & Signifikan \\
\hline
\end{tabular}

Tabel 4 menunjukan bahwa semua parameter signifikan karena nilai p-value $>0,05$. Selanjutnya dilakukan pengecekan kelayakan model dengan menguji asumsi white noise dan normalitas dari residual model yang dihasilkan. Hasil uji asumsi seperti pada Tabel 5.

Tabel 5. Uji White Noise Residual Model Akhir Fungsi Transfer Multi Input (FTMI) dengan Deteksi Outlier

\begin{tabular}{|c|c|c|c|c|}
\hline Model & Lag & Chi-Square & P-value & Keputusan \\
\hline & 6 & 3.02 & 0.3890 & \\
\cline { 2 - 4 } FTMI & 12 & 12.10 & 0.2076 & \\
\cline { 2 - 4 }$(b=0, r=0, s=2)$ & 18 & 19.81 & 0.1794 & \\
\cline { 2 - 4 }$(b=0, r=0, s=0)$ & 24 & 22.69 & 0.3605 & \multirow{2}{*}{ White noise } \\
\cline { 2 - 4 } ARIMA $([8],[1,21])$ & 30 & 28.98 & 0.3620 & \\
Dengan Deteksi & 36 & 32.34 & 0.4998 & \\
\cline { 2 - 4 } Outlier & 42 & 43.61 & 0.2817 & \\
\cline { 2 - 4 } & 48 & 46.77 & 0.3997 & \\
\hline
\end{tabular}

Berdasarkan Tabel 5, model fungsi transfer multi input dengan deteksi outlier sudah memenuhi asumsi white noise dengan nilai p-value $>0,05$ pada semua lag. Model akhir fungsi transfer multi input dengan deteksi outlier yang terbentuk adalah:

$$
\begin{aligned}
Y_{t}=1.08721 X_{1, t} & -0.94511 X_{1, t-1}-0.03607 X_{1, t-2}-0.29477 X_{2, t}+0.29477 X_{2, t-1} \\
& +\frac{2.58556}{1-B} I_{t}^{T=1914}+\frac{3.76015}{1-B} I_{t}^{T=1955}+\frac{2.36799}{1-B} I_{t}^{T=1500}+\frac{2.88466}{1-B} I_{t}^{T=521} \\
& -\frac{2.74858}{1-B} I_{t}^{T=2315}-\frac{1.93683}{1-B} I_{t}^{T=495}+\frac{4.16608}{1-B} I_{t}^{T=438}+6.71760 I_{t}^{T=738}-\cdots \\
& -3.40290 I_{t}^{T=411}+\frac{\left(1-0.97808 B^{1}+0.08653 B^{21}\right) a_{t}}{\left(1+0.07062 B^{8}\right)}+Y_{t-1}
\end{aligned}
$$

Nilai RMSE yang diperoleh dari hasil peramalan data out-sample untuk jangka waktu 31 hari ke depan menggunakan model fungsi transfer multi input adalah 11,6052 yang berarti bahwa peramalan curah hujan di Kota Surabaya dengan model fungsi transfer multi input hampir mendekati data aktualnya.

\section{KESIMPULAN}

Berdasarkan hasil analisis diperoleh model fungsi transfer multi input untuk peramalan curah hujan di Kota Surabaya dapat dipengaruhi oleh suhu dan kelembaban udara. Nilai RMSE yang diperoleh dari hasil peramalan data out-sample untuk jangka waktu 31 hari ke depan menggunakan model fungsi transfer multi input adalah 11,6052 sehingga dapat disimpulkan peramalan curah hujan dengan menggunakan model fungsi transfer multi input, lebih baik dibandingan beberapa metode peramalan yang digunakan sebelumnya. 


\section{DAFTAR PUSTAKA}

[1] Badan Pusat Statistik Kota Surabaya, “Kota Surabaya dalam Angka,” Surabaya, 2014.

[2] Mauludiyanto, A., Hendrantoro, G., Hery, P.M. dan Suhartono, "Pemodelan Varima dengan Efek Deteksi Outlier Terhadap Data Curah Hujan," Jurnal Ilmiah Teknologi Informasi, Institut Teknologi Sepuluh November, Surabaya, vol. 7, 2009.

[3] Huda, A.M., Achmad C., Osaliana, B. dan Sutikno, "Peramalan Data Curah Hujan Dengan Seasonal Autoregregressive Integrated Moving Average (SARIMA)," dalam Seminar Nasional: Kedaulatan Pangan dan Energi, Madura, 2012.

[4] Wilson, E.M, Hidrologi Teknik, Edisi ke-4, Jakarta: Erlangga, 1993.

[5] S. C. Wheeleright, E. M. Victor dan S. Makridakis, Metode Dan Aplikasi Peramalan. Edisi kedua, Jakarta: Bina Rupa Aksara, 1999.

[6] Nwobi-Okoye, C.C., Okiy, S. dan Igboanugo, A.C, "Performance Evaluation of Multi-Input-SingleOutput (MISO) Production Process Using Transfer Function and Logic Fuzzy (Case Study Of A Brewery)," Ain Shams Engineering Journal, Ain Shams University, vol. 7, 2015.

[7] Otok, B.W. dan Suhartono, "Peluang Bisnis Pada Jasa Kereta Api Indonesia Dalam Menyikapi Krisis Ekonomi (Kajian Analisis Intervensi dan Fungsi Transfer)," Natural Jurnal, FMIPA, Universitas Brawijaya, vol. 6 (Edisi Khusus), 2001.

[8] Wei, W.W.S, Time Series Analysis Univariate and Multivariat Methods, New York: Addison-Wesley Company Inc, 2006. 